\title{
The Importance of Training for Human Resource Development in Organization
}

\author{
Astuty Mulang \\ Indonesia Timur University of Makassar
}

doi:10.5296/jpag.v5i1.7505

URL: http://dx.doi.org/10.5296/jpag.v5i1.7505

\begin{abstract}
Human resource makes up primary element of an organization. Human resource training and development are absolute necessities for it. In pragmatic, training and development program have positive influence on both individual and organization. Training Need Analysis (TNA). performance problem, new system and technology and also automatic and habitual training. It is a need analysis at the workplace which is specifically meant to find what actually training needs as a priority. Information of the needs will help organization in employing resources effectively and prevent unnecessary training activity.
\end{abstract}

Keywords: Human Resource, training and development, training need analysis 


\section{Introduction}

Human resource is the primary element of organization in comparison with other elements, such as capital, technology and financial as the human resource functions as other elements control. Discussing about human resource, it will not be escaped from other management activities or processes including planning strategy, management development and organization development. Relevance to theses management aspects is so close that it is hard for us to get out of discussing one element and others in a separate (Coens, T., \& Jenkins, M. 2000)..

Training for human resource development is a must in an organization when direct employment placement cannot warrant employee's success. New comer often faces uncertainty on his role and responsibility. Job demand and staff capacity shall be in state of balance through orientation and training program (Coens, T., \& Jenkins, M. 2000).. The two programs are required. Once the staffs are trained and acquired skills in their job, they need further improvement to make preparation on responsibilities in the future. A tendency keeps on being happened where the more varied staffs with a flatter organization and hardening global competition, training and development may promote the staffs in handling the harder duty, responsibility and obligation (Colquitt, et al.,. 2001).

\section{The Definition of Training}

Latham, G. P., \& Dello Russo, S. (2008). propose: "training and development are terms referring to planned efforts designed facilitate the acquisition of relevant skills, knowledge, and attitudes by organizational members". Then, Wexley and Yukl also explain that : "development focuses more on improving the decision making and human relation skills of middle and upper level management, while training involves lower level employees and the presentation of more factual and narrow subject matter"

Ideas of Wexley and Yukl explain more the use of training term in an organization. They have an opinion that training in human resource development are terms referring to planned efforts, designed facilitate the acquisition of skills, knowledge, and attitudes by organizational staffs or members. The development focuses more on improving the decision making and expanding human relation skills of upper and middle level management, while training is meant for lower level employees (doer).

Definition of staff training and development is proposed by Grubb, T. (2007). "training is short-terms educational procces utilizing a systematic and organized procedure by which nonmanagerial personnel learn technical knowlegde and skills for a definite purpose. Development, in reference to staffing and personnel matters, is a long-terms educational process utilizing a systematic and organized procedure by which managerial personnel learn conceptual and theoritical knowledge for general purpose”.

The term of training is intended to executing staff in improving knowledge and technical skills, while development is destined for managerial personnel to improve conceptual skills, decision making skills and expand human relation. 
Lawler, E. E., III. (1977). suggests that training and development may be defined as planned efforts made by the organization to develop staff's knowledge, skills, and capabilities. Further, Mariot Tua states that training and development are two same concepts, i.e. improvement of knowledge, skills and capabilities. Concerning on the objectives, these two concepts are distinguishable. Training is focused more on capability improvement for current specific purposes, while development is focused more on knowledge improvement for future job where the process is carried out in integrative ways with other activities to better work behavior.

According to Mani, B. (2002). training for staff constitutes a process that gives specific knowledge and skills, and also behavior in purpose to let the staffs skilled and be able to perform their responsibilities better relevant with the standard. In this case, development has a broader scope. It may form an effort to upgrade knowledge that will be used soon or frequent for future interest. Development is often categorized in explicit for management development, organization development and personal development. However, it mainly focuses on management development. On the other word, it does not focus on current and future job, but on long-term organization need accomplishment (Kuvaas, B. 2011)..

\section{Rationalization of Training and Development}

In pragmatic, training and development program have positive influence on both individual and organization. Smither, et al., (2005), explains that individual capability profile relates to skills the staff gains from training and development. In proportion to the acquisition of skills and competence, individual income will increase. At last, output of training and development will open an opportunity for individual career development. In this context, career development or promotion is specified by ownership or skill qualification. When organization has a hard time, it tends to lower headcounts; thus, training and development strengthen individual through job security warranty by virtue of competence acquisition. The organization requirement covers:

1. Training and development have the potential to improve labour productivity;

2. Training and development can improve quality of that output, a more highly trained employee is not only more competent at the job but also more aware of the significance of his or her action;

3. Training and development improve the ability of the organization to cope with change; the success implementation of change whether technical (in the form of new technologies) or strategic (new product, new markets, etc.) relies on the skill of the organization's member (mither, et al., 2005),

When competition between organizations happens so tight, productivity becomes one of organization's viability determining factors in addition to staff's quality and competence. Human resource training and development are able to warrant attainment of the three matters in organization level. 


\section{Indicative Phenomena of Training and Development}

There are some organizational phenomena that are categorized as indicative phenomena at the time when a need for training and development appears. If work achievement standard is unrealized, employee will be incapable of performing his duties and unproductive, while decreasing selling rate and profit are some general indications that appear in organization.

Phenomena arising from the condition, according to Belschak, F. D., \& Hartog, D. N. D. (2009). are seven main phenomena in organization that needs handling as follows:

1. Low productivity;

2. High absenteeism;

3. High turnover;

4. Low employee morale;

5. High grievances;

6. Strike;

7. Low profitability.

\section{The Relationship between Causative Factors and Organizational Phenomena}

The seven phenomena is generally found in organization as the result of at least three factors: fail to motivate employees, failure of organization to provide facilities and right opportunity for employees in performing the jobs, failure of organization to provide effective training and development for employees. In such condition, training program relies highly on training need analysis ( TNA). It is staff development-oriented including:

1. Arrival of new staff has an orientation of organizational jobs or principle duties towards newly recruited staff before placement to one of organization units;

2. A presence of new work equipment, Makes the staff ready to utilize the new equipment with its new technology that it will prevent occupational hazards and improve work efficiency;

3. Changes of management system/bureaucratic administration, Makes the staff ready for the job through newly established system;

4. The presence of new work quality standard, Prepares the staff for the job through newly established system;

5. Needs for memory refresh, Refreshes knowledge and skills the staff have achieved in a new atmosphere/nuance;

6. Declining staff performance, Improves staff performance quality as demanded by the strategic environmental development;

7. Employee rotation/relocation, Improves staff's competence to handle new jobs and work 
situation.

\section{Training Plan Stages}

\subsection{Training Need Analysis (TNA)}

In the first step of TNA, organization requires assessment phase marked out by one key activity, i.e. training need analysis. There are three situations where the organization is compelled to conduct the analysis including performance problem, new system and technology and also automatic and habitual training.

The first situation, relates to performance at which the staff faces quality degradation or gap between performance and the established work standard. Second situation, relates to computer use, new procedure and technology which are adopted to reform efficiency in firm operation.

Third situation, relates to the training that is carried out and grounded on specific requirements, for example legal liability (for some health and safety at work).

Training Need Analysis (TNA) is a workplace needs analysis specifically intended to find what actually training needs as the priority. Information of the needs will help organization in making use of resources (fund, time, etc.) in effective as well to prevent unnecessary training activity. TNA may also mean as a systematic and comprehensive investigation about varied problems to identify some problem dimensions accurately. Accordingly, the organization will find out if the problem shall be solved through training program or otherwise. Training need analysis is executed by (asking question getting answers) method. Questions are given to every employee, and it is tailed by verification and documentation on various problems where finally, the training need will be known to solve problems. Problems in need of training always relate to lack of skill or knowledge were standard performance is unobtainable. Accordingly, explanation above clarifies the difference between actual performance and situational performance.

Below are functions of Training Need Analysis (TNA):

1. collects information on skill, knowledge and feeling of the employee;

2. collects information on job content and job context;

3. defines standard performance and actual performance in operation;

4. involves stakeholders and gathers their support;

5. provides data for planning needs.

The output of Training Need Analysis (TNA) is identification of performance gap. Performance gap can be identified as difference between expected performance and actual performance of individual. Performance gap is detectable through identification and documentation of competence standard or requirement to be fulfilled in job performance. The 


\section{Macrothink \\ Journal of Public Administration and Governance \\ ISSN 2161-7104 \\ 2015, Vol. 5, No. 1}

requirement, then, is adjusted to actual performance of individual at the workplace.

Training Need Analysis (TNA) stages have main elements as follows:

- problem identification

- need identification

- performance standard development

- participant identification

- training criteria expansion

- cost estimate

- profit

Training design making is the essence of training; it is a step on how we may convince that training will be held. Overall duty carried out in this stage involves:

1. identifies learning goal of training program;

2. sets an accurate method;

3. appoints the organizer along with other support;

4. takes out the correct media among various ones;

5. sets the content;

6. identifies evaluation instruments;

7. makes arrangement of training order.

Further, not less important than previous stages is training material making which will be needed and developed as follows:

1. overall training schedule (time estimation);

2. plan for every single session;

3. learning materials, for example note book, textbook, handout, etc.;

4. instructional aid;

5. evaluation form.

\subsection{Training Program Implementation}

Next step to establish an effective training activity shall be an implementation of training program. Success of training program implementation and human resource development depends on program selection in order to take out the right people under the right conditions. Training Need Analysis (TNA) can help to identify the right people and the right program, 
while some training development and consideration program can help to create the right condition.

\subsection{Training Evaluation}

To ascertain the success of training, evaluation is a necessary. Systematically, training management covers planning stage including training need analysis, implementation and evaluation. The end stage is critical point in every activity as it is frequently ignored even if it is a vital part to ascertain if the training is success in achieving the goals or otherwise.

1. Perception of training evaluation concept has faced perceptual problem long since. As an activity, perception of many organization about evaluation are mistaken, even they ignore or never take evaluation after the training held. According to Bouskila-Yam, O., \& Kluger, A. N. (2011).), training program and development evaluation is necessary and useful acitivity; however, it is practically forgotten or come undone.

2. Meaning of training evaluation as written by Newby Heslin, P. A., \& Latham, G. P. (2004).) is that main notice of evaluation is focused on training effectiveness. Effectiveness relates to the extent of human resource training program is made the goal to be achieved as it is crucial in training evaluation.

3. Evaluation training is made by training organizer as follows:

Pre-training Evaluation, aims to find out the extent of knowledge, skills and attitude performed by participants before the training program compared to the knowledge, skills and attitute arranged in the program. Knowledge, skills and attitude which have not possessed by participants are made in list of training program implementation. Evaluation stages for the training program:

- Evaluation of Participant

- Evaluation of Widyaiswara

- Organizer Performance Evaluation

Post-Training Evaluation, aims to find out knowledge, skills and attitude which were not possessed by participants, but when the training is over, they are well-possessed by participants.

\section{Conclusion}

Human resource is a prominent element in an organization compared to other elements like capital, technology and fund as it is the human itself who will control the side elements. Training and development can be defined as planned effort from the organization to improve staff's knowledge, skills and competence. Training and development are two same concepts, i.e. to improve knowledge, skills and capabilities. However, concerning on the objectives, these two concepts are distinguishable. Training is focused more on capability improvement for current specific purposes, while development is focused more on knowledge improvement for future job where the process is carried out in integrative ways with other activities to 


\section{Macrothink}

better work behavior. Training Need Analysis (TNA) is a workplace needs analysis specifically intended to find what actually training needs as the priority.

Information of the needs will help organization in making use of resources (fund, time, etc.) in effective as well to prevent unnecessary training activity.

\section{References}

Belschak, F. D., \& Hartog, D. N. D. (2009). Consequences of positive and negative feedback: The impact on emotions and extra-role behaviors. Applied Psychology: An International Review, 58, 274-303.

Bouskila-Yam, O., \& Kluger, A. N. (2011). Strengthbased performance appraisal and goal setting. Human Resource Management Review, 21, 137-147.

Coens, T., \& Jenkins, M. (2000). Abolishing performance appraisals: Why they backfi re and what to do instead. San Francisco, CA: Berrett-Koehler.

Colquitt, J. A., Conlon, D. E., Wesson, M. J., Porter, C. O. L. H., \& Ng, K. Y. (2001). Justice at the millennium: A meta-analytic review of 25 years of organizational justice research. Journal of Applied Psychology, 86, 425-445.

Folger, R., \& Cropanzano, R. (1998). Organizational justice and human resource management. Thousand Oaks, CA: Sage.

Grubb, T. (2007). Performance appraisal reappraised: It's not all positive. Journal of Human Resource Education, 1, 1-22.

Heslin, P. A., \& Latham, G. P. (2004). The effect of upward feedback on managerial behavior. Applied Psychology: An International Review, 53, 23-37.

Kuvaas, B. (2011). The interactive role of performance appraisal reactions and regular feedback. Journal of Managerial Psychology, 26, 123-137.

Latham, G. P., \& Dello Russo, S. (2008). The infl uence of organizational politics on performance appraisal. In C. Cooper \& S. Cartwright (Eds.), The Oxford handbook of personnel psychology (pp. 388-410).

Lawler, E. E., III. (1977). Adaptive experiments: An approach to organizational behavior research. Academy of Management Review, 2, 576-585.

Mani, B. (2002). Performance appraisal systems, productivity, and motivation: A case study. Public Personnel Management, 31, 141-159.

Smither, J. W., London, M., \& Reilly, R. R. (2005). Does performance improve following multisource feedback? A theoretical model, meta-analysis, and review of empirical fi ndings. Personnel Psychology, 59, 33-66. 